\title{
Nitrogen Status and Light Environment Influence Dry Matter Partitioning in Cauliflower
}

\author{
C. Alt, ${ }^{1}$ H. Kage, ${ }^{2}$ and H. Stüitzel ${ }^{3}$ \\ Institute for Vegetable and Fruit Crops, University of Hannover, 30419 Hannover, Germany
}

\begin{abstract}
ADDITIONAL INDEX wORDs. carbon partitioning, model, source-sink concept, generative growth, vegetative growth, Brassica oleracea

Abstract. Concepts of above-ground dry matter partitioning in cauliflower [Brassica oleracea L. (Botrytis Group)] as dependent on nitrogen $(\mathrm{N})$ supply and light environment are presented. Leaf and stem partitioning depends on a functional relationship between stem dry weight and leaf area, independent of $\mathrm{N}$ status. Dry matter partitioning into the inflorescence is sink-limited (potential capacity) at the beginning, and source limited (daily available assimilates) later. The intrinsic specific growth rate of the inflorescence is dependent on leaf $\mathrm{N}$ content. The model is parameterized and evaluated with data from field experiments. Applied to an independent data set, the model predictions of proportions of inflorescence, leaf, and stem on total dry matter corresponded with measurements $(r=0.84,0.92$ and 0.22 , respectively) for different $\mathbf{N}$ fertilization rates and light treatments.
\end{abstract}

Dependence of dry matter distribution on environmental conditions and nitrogen $(\mathrm{N})$ supply has been reported for various species (Brouwer, 1962b; Hirose, 1986; Marcelis, 1994). In vegetables, the relative amount of dry matter distributed to the marketable product is influenced also in different ways by $\mathrm{N}$ availability (Biemond, 1995).

Dry matter partitioning is characterized by a net flow of assimilates from source to sink organs. Although the mediating regulators of this flow (Munns and Cramer, 1996; Van der Werf and Nagel, 1996) as well as control strategies (Reynolds and Chen, 1996) are not fully understood, four models of biomass allocation have emerged: 1) partitioning coefficients described by empirical constants, often as functions of developmental stage (Penning de Vries et al., 1989); 2) allometric growth between different organs, i.e., fixed ratios between relative growth rates (Kage and Stützel, 1999; Pearsall, 1927; Stützel and Aufhammer, 1991); 3) functional balance between root and shoot activity, first applied by Brouwer (1962a) and further developed to be regulated by C:N distribution (Johnson and Thornley, 1987) or N concentration in the plant (Agren and Ingestad; 1987; Levin et al., 1989); and 4) sink-based models in which dry matter distribution is regulated by the sink strength partly including the transport path (Chamont, 1993; Jones et al., 1991; Marcelis, 1993; Wien, 1997).

Although terms like (potential) sink strength and sink activity are used widely, they are neither uniquely defined nor is their usefulness generally accepted (Farrar, 1993). Wolfswinkel (1985) expressed sink strength as the maximum, i.e., source-unlimited, dry matter uptake of an organ, which may be related to the potential growth rate of the sink under nonlimiting assimilate supply (Marcelis et al., 1989).

Empirical and allometric models are usually more easily parameterized than sink strength based models but have little explanatory value and may have limited application under chang-

\footnotetext{
Received for publication 13 Mar. 2000. Accepted for publication 19 June 2001. We thank H.-J. Wiebe for detailed information about his cauliflower development model as well as A. van der Werf for helpful comments on the manuscript. Technical assistance of I. Lippert and E. Diedrich is gratefully acknowledged. ${ }^{1}$ Postdoctoral fellow. The cost of publishing this paper was defrayed in part by the payment of page charges. Under postal regulations, this paper therefore must be hereby marked advertisement solely to indicate this fact.

${ }^{2}$ Assistant professor.

${ }^{3}$ Professor and corresponding author; e-mail: stuetzel@gem.uni-hannover.de.
}

ing environmental conditions. Models for development and dry matter partitioning as well as total dry matter production of cauliflower [Brassica oleracea (Botrytis Group)] have been published (Kage and Stützel, 1999; Kage et al., 2000; Kage et al., 2001a, 2001b; Olesen and Grevsen, 1997; Wheeler et al., 1995; Wiebe, 1972a, 1972b; Wurr et al., 1990) but functional relationships between productivity and dry matter partitioning have been ignored consistently.

Therefore, the objective of the following study was to evaluate the influence of productivity of cauliflower crops, which may be quantified by their relative or absolute growth rate, on the process of dry matter partitioning. Since dry matter production in cauliflower is dependent largely on radiation and $\mathrm{N}$ content, both factors were varied in field experiments and their influence on dry matter partitioning was evaluated. Hypotheses for partitioning of above-ground dry matter as dependent on $\mathrm{N}$ status and light environment were formulated and tested using the data from the field experiments. Partitioning of dry matter into the root system was neglected for reasons of simplicity, since it stores the least amount of $\mathrm{N}$ due to a relatively small proportion on total dry weight $\left(\mathrm{W}_{\mathrm{p}}\right)$ and a $\mathrm{N}$ concentration of about $2 \%$ (unpublished data). Together with approaches for describing the productivity $\mathrm{N}$ content relationship (Alt, et al., 2000), an integrated model of the cauliflower crop may be built and used for the development of profitable and environmentally safe production practices.

\section{Material and Methods}

MoDEL. Symbols, definitions, and units are presented in Table 1. The total above-ground growth rate, $\mathrm{dW}_{\mathrm{p}} / \mathrm{dt}$, is the sum of the dry matter increases of vegetative and generative organs, $\mathrm{dW}_{\mathrm{v}} / \mathrm{dt}$ and $\mathrm{dW}_{\mathrm{g}} / \mathrm{dt}$, respectively:

$d W_{p} / d t=d W_{v} / d t+d W_{g} / d t$

It is assumed that one fraction of stem dry matter, $\mathrm{W}_{\mathrm{s}, \mathrm{l}}$, is associated with leaf growth, $\mathrm{dW}_{\text {leaf }} / \mathrm{dt}$, and that another fraction, $\mathrm{W}_{\mathrm{s}, \mathrm{in}}$, is related to inflorescence growth. Thus:

$d W_{\mathrm{v}} / d t=d W_{s,} / d t+d W_{\text {leaf }} / d t$

where $\mathrm{W}_{\mathrm{s}, 1}$ is assumed to be proportional to leaf area, $\mathrm{A}_{1}$ :

$\mathbf{W}_{\mathrm{s}, \mathrm{l}} / \mathbf{d t}=\mathrm{a} \times \mathrm{A}_{\mathbf{l}}$

Parameter a can be interpreted as the increase in stem growth 
Table 1. Symbols, definitions, and units used in model development and evaluation.

\begin{tabular}{|c|c|c|}
\hline Symbol & Definition & Unit \\
\hline $\mathrm{a}$ & Increase in stem dry matter per increase in leaf area & $\mathrm{g} \cdot \mathrm{m}^{-2}$ \\
\hline $\mathrm{A}_{1}$ & Leaf area & $\mathrm{m}^{2} /$ plant \\
\hline $\mathrm{dV} / \mathrm{dt}$ & Daily rate of vernalization & $\mathrm{d}^{-1}$ \\
\hline $\mathrm{f}_{\text {stem }}$ & Stem partitioning coefficient & --- \\
\hline $\mathrm{n}_{\text {area }}$ & $\mathrm{N}$ content per unit leaf area & $\mathrm{g} \cdot \mathrm{m}^{-2}$ \\
\hline $\mathrm{no}_{\text {leaf }}$ & Number of visible leaves & --- \\
\hline rgr $_{\text {in }}$ & Relative growth rate of inflorescence & $\mathrm{d}^{-1}$ \\
\hline sla & Specific leaf area (leaf area per unit of leaf dry matter) & $\mathrm{m}^{2} \cdot \mathrm{g}^{-1}$ \\
\hline $\mathrm{T}$ & Temperature & ${ }^{\circ} \mathrm{C}$ \\
\hline $\mathrm{v}_{\max }$ & Maximum daily rate of vernalization & $\mathrm{d}^{-1}$ \\
\hline $\mathrm{W}_{\mathrm{g}}$ & Dry weight associated with generative growth & g/plant \\
\hline $\mathrm{W}_{\text {in }}^{\mathrm{g}}$ & Inflorescence dry weight & $\mathrm{g} /$ plant \\
\hline $\mathrm{W}_{\text {in,cap }}$ & Potential sink capacity of the inflorescence & $\mathrm{g} /$ plant \\
\hline $\mathrm{W}_{\text {leaf }}$ & Leaf dry weight & $\mathrm{g} /$ plant \\
\hline $\mathrm{W}_{\mathrm{p}}$ & Above-ground dry weight & $\mathrm{g} /$ plant \\
\hline $\mathrm{W}_{\mathrm{s}, \mathrm{in}}^{\mathrm{p}}$ & Stem dry weight associated with inflorescence growth & g/plant \\
\hline $\mathrm{W}_{\mathrm{s}, \mathrm{s}}^{\mathrm{s}, \mathrm{Ii}}$ & Stem dry weight associated with leaf growth & g/plant \\
\hline $\mathrm{W}_{\mathrm{stem}}$ & Stem dry weight & g/plant \\
\hline $\mathrm{W}_{\mathrm{v}}$ & Vegetative dry weight & $\mathrm{g} /$ plant \\
\hline
\end{tabular}

per increase in leaf area necessary for structural support of the leaf. It is proposed that the stability requirement of the plant is mainly determined by leaf area susceptible to wind.

If the specific leaf area, sla, is constant,

$$
\mathbf{A}_{1}=\text { sla } \times \mathbf{W}_{\text {leaf }}
$$

then Eq. [2] can be rewritten to calculate dry matter increase of stem and leaf:

$$
\begin{aligned}
& d W_{\text {leaf }} / d t=(1 /(1+a \times s l a))\left(d W_{v} / d t\right) \\
& d W_{s, l} / d t=d W_{v} / d t-d W_{\text {leaf }} / d t
\end{aligned}
$$

In case of varying specific leaf area during plant growth the same equations apply, and sla in Eq. [5] refers to the relevant specific leaf area of the newly produced leaf dry matter.

When vernalization is completed, the inflorescence starts to initiate. From then, generative growth has priority over vegetative growth in order to satisfy the potential sink capacity of the inflorescence, $\mathrm{dW}_{\text {in,cap }} / \mathrm{dt}$, which is determined by its dry matter, $\mathrm{W}_{\text {in }}$, and its relative growth rate, $\operatorname{rgr}_{\text {in }}$ :

$$
\mathrm{dW}_{\text {in,cap }} / \mathrm{dt}=\operatorname{rgr}_{\text {in }} \mathrm{W}_{\text {in }}
$$

Following an original concept of Warren-Wilson (1967), rgr $_{\text {in }}$ may be related to the sink activity, whereas $W_{\text {in }}$ is a measure of sink size.

The initial dry matter of the inflorescence was set to $6.4 \times 10^{-6} \mathrm{~g} /$ plant estimated as $10 \%$ of a water filled sphere with a diameter of $0.6 \mathrm{~mm}$ which, is the approximate diameter of the apical dome at the beginning of inflorescence growth (Wiebe, 1972b).

The specific growth rate is assumed to vary with the $\mathrm{N}$ content of the plant at the time of inflorescence initiation:

$$
\operatorname{rgr}_{\text {in }}=\text { function }(\mathrm{N} \text { content })
$$

Accelerated inflorescence growth with better $\mathrm{N}$ supply may be explained by an increased number of inflorescence cells initiated, or an increased supply rate of available protein $\mathrm{N}$ compounds during cell elongation. Both would increase the sink capacity of the inflorescence.

Stem growth would be increased with every increment in inflorescence dry weight to meet the increased structural and physiological demands of the inflorescence:

$$
d W_{\text {s,in }} / d t=f_{\text {stem }}\left(d W_{\text {in }} / d t\right)
$$

where $\mathrm{f}_{\text {stem }}$ denotes the fraction of $\mathrm{dW}_{\text {in }} / \mathrm{dt}$ associated with stem growth.

The total generative growth rate is the sum of inflorescence and associated stem growth:

$$
d W_{\mathrm{g}} / \mathrm{dt}=\mathbf{d W _ { \text { in } }} / \mathrm{dt}+\mathbf{d W _ { \mathrm { s } , \text { in } }}=\left(1+\mathrm{f}_{\text {stem }}\right) \times\left(\mathbf{d W _ { \text { in } }} / \mathrm{dt}\right)
$$

With increasing $\mathrm{W}_{\text {in }}$ the proportion of generative growth in the total plant growth is continuously increasing until generative growth is limited by total growth rate imposing an upper limit to inflorescence growth rate. The dry matter increase of the inflorescence is initially limited by its sink capacity (Eq. [7]), and subsequently by total available assimilates:

\begin{tabular}{|c|c|c|c|c|c|}
\hline Year & $\begin{array}{c}\text { Sowing } \\
\text { date }\end{array}$ & $\begin{array}{c}\text { Transplanting } \\
\text { date }\end{array}$ & $\begin{array}{c}\text { Harvests } \\
\text { (days after } \\
\text { transplanting) }\end{array}$ & $\begin{array}{c}\text { Leaf } \\
\text { no. }\end{array}$ & $\begin{array}{c}\mathrm{W}_{\mathrm{v}} \\
\text { (g dry wt/ } \\
\text { plant) }\end{array}$ \\
\hline$\overline{1996}$ & 23 May & 18 June & $28,49,69$ & 3.25 & 0.34 \\
\hline 1997 & 3 June & 9 July & $26,47,68^{z}, 82$ & 3.5 & 0.39 \\
\hline
\end{tabular}

$$
d W_{\text {in }} / d t=\min \left(1 /\left(1+f_{\text {stem }}\right)\right)\left(d W_{\text {p }} / d t\right),\left(d W_{\text {in,cap }} / d t\right)
$$

Before the vernalization process is completed $\mathrm{dW}_{\text {in }} / \mathrm{dt}$ is set to zero. Given the inflorescence growth rate the leaf and total stem growth rates can be calculated:

Table 2. Dates of sowing, transplanting, and harvesting of field experiments and average visible leaf number, and dry weight of transplants.

${ }^{\mathrm{z}}$ Final harvest of $\mathrm{N}$-fertilized treatments of nonshaded light environment (Table 3). 
Table 3. Light environments and $\mathrm{N}$ applications in both experiments.

\begin{tabular}{lcc}
\hline \hline Factor & Level & Abbreviation \\
\hline Light environment & Nonshaded & L1 \\
& Shaded & L2 \\
N application & 0 & N0 \\
Target values $\left(\mathrm{N}, \mathrm{kg} \cdot \mathrm{ha}^{-1}\right)^{\mathrm{z}}$ & 150 & $\mathrm{~N} 1$ \\
& 300 & $\mathrm{~N} 2$ \\
& 450 & $\mathrm{~N} 3$
\end{tabular}

${ }^{\mathrm{z}}$ Soil nitrate N content ( 0 to $60 \mathrm{~cm}$ depth) of 10 to $15 \mathrm{~kg} \cdot \mathrm{ha}^{-1}$ in 1996 and 1997 were subtracted from the target values.

$$
\begin{aligned}
& \mathrm{dW}_{\text {lead }} / \mathrm{dt}=1 /(1+\mathrm{a} \times \mathrm{sla})\left[\left(\mathrm{dW}_{\mathrm{p}} / \mathrm{dt}\right)-\left(1+\mathrm{f}_{\text {stem }}\right)\left(\mathrm{dW}_{\text {in }} / \mathrm{dt}\right)\right]
\end{aligned}
$$

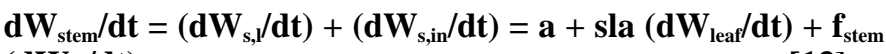

$$
\begin{aligned}
& \left(\mathbf{d W}_{\text {in }} / \mathbf{d t}\right) \\
& \text { [13] }
\end{aligned}
$$

Field EXPERIMENTS. Two independent field experiments with 'Fremont' cauliflower were conducted at the experimental farm of the Institute for Vegetable and Fruit Crops located $15 \mathrm{~km}$ south of Hannover, Germany, on a typical loess derived hapludalf soil. The 1996 experiment conducted during June to September was used for derivation of model parameters and the 1997 experiment conducted during July to September served for model evaluation (Table 2).

The experiments were designed as split plots with two light environments as main plots and four $\mathrm{N}$ fertilizer levels as subplots (Table 3) and three replications. Main plots of the shaded treatments were covered $1 \mathrm{~m}$ above the ground with a shading net absorbing $40 \%$ of photosynthetically active radiation (PAR) immediately after transplanting (1996) or 2 weeks after transplanting (1997). PAR was measured using a line quantum sensor (LI-191 SA; LI-COR, Inc., Lincoln, Nebr.). The size of the plots was $\approx 2 \times 10 \mathrm{~m}$ and the planting pattern was $0.6 \times 0.48 \mathrm{~m}$ giving an average density of 3.5 plants $/ \mathrm{m}^{2}$. Average dry weight of the transplants was $0.34 \mathrm{~g}$ in 1996 and $0.39 \mathrm{~g}$ in 1997 . Before planting chlorfenvinphos and molybdenum sulphate were applied prophylactically against cabbage fly (Delia brassicae Wied.) and molybdenium deficiency, respectively. Insect infestations were prevented with one spraying of oxodemeton-methyl and parathion each year. Weeds were controlled by hand weeding. Nitrogen fertilization was provided as ammonium nitrate at the time of transplanting with rates according to the scheme presented in Table 3.

Plant growth analysis. On several intermediate harvests in both years, six plants per plot were harvested and separated into stems, leaves including petioles, and the inflorescences. Plants were cut $1 \mathrm{~cm}$ below the soil line and the stem was separated from the rest of the plant at the level of the onset of the inflorescence. The foliage was subdivided further into groups of five consecutive leaves ( 1 to 5,6 to 10 , etc.). Leaf number corresponded to leaf appearance. Leaf area of every leaf group was measured with a leaf area meter (LI-3100; LI-COR, Inc.). Samples of all plant components were oven dried at $70{ }^{\circ} \mathrm{C}$ for $12 \mathrm{~h}$ followed by a period of $6 \mathrm{~h}$ at $105^{\circ} \mathrm{C}$ and weighed. After weighing, total $\mathrm{N}$ and nitrate $\mathrm{N}$ were determined by the micro-Kjeldahl method and a nitrate selective electrode, respectively. At all harvests, plant height and width and inflorescence diameter were also measured. For width measurements, a graduated ruler was placed above the plants in the field and the horizontal extension of every plant was measured four times and averaged.

Statistical analysis and MOdel Parameterization. Statis- tical analyses were carried out using NLIN and REG procedures of SAS (SAS Inst., Inc., 1988). The level of significance was calculated with an error probability of $P=0.05$. Above-ground plant growth rate served as an input variable for dry matter distribution (Eq. [11] to [13) and was calculated by interpolating the experimental data with an expolinear function (Goudriaan and Monteith, 1990). The average specific leaf areas of the shaded and nonshaded light environments were also used as input parameters to calculate leaf area from simulated leaf dry weights.

The dynamic model of development and partitioning described previously was programmed using the modelling environment ModelMaker (Walker, 1997). The integration was performed using the Euler algorithm (Thornley and Johnson, 1990) with a time step of $1 \mathrm{~d}$. A nonlinear least-squares regression analysis estimates the parameters $\mathrm{f}_{\text {stem }}$ (Eq. [9]), and $\operatorname{rgr}_{\text {in }}$ (Eq. [7]), using a Marquardt optimization algorithm (Marquardt, 1963). Together with the estimate of the parameter value, the software gives the value of the square root of the diagonal elements of the covariance matrix. Multiplying this value with the square root of the mean square of the residual yields the asymptotic standard error of the coefficient (Gallant, 1987).

Cauliflower development. Leaf appearance rate were described following Kage and Stützel (1999) where visible leaf number is expressed as an expolinear function of the temperature sum with parameters $k_{1}$ and $k_{2}$. The values of the parameters for the cultivar Fremont were determined from an independent experiment in 1998 as $\mathrm{k}_{1}=0.0032 \pm 0.0001\left(\mathrm{~d}^{-10} \mathrm{C}^{-1}\right)$ and $\mathrm{k}_{2}=$ $0.0353 \pm 0.0036\left(\right.$ leaf $\left.\times \mathrm{d}^{-10} \mathrm{C}^{-1}\right)$ (unpublished data).

The vernalization process was calculated according to Wiebe (1972a) using a daily vernalization rate, $\mathrm{dV} / \mathrm{dt}$, which is a function of mean daily temperature, $\mathrm{T}$ :

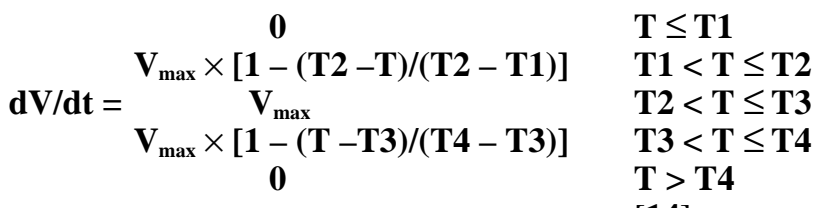

[14]

where $\mathrm{v}_{\max }$ is the maximum vernalization rate set to $0.11 / \mathrm{d}$. The four temperatures $\mathrm{T} 1$ to $\mathrm{T} 4$ are cultivar dependent and assumed to be $0,10,13$, and $28^{\circ} \mathrm{C}$ for the cultivar Fremont (H.-J. Wiebe, personal communication). The vernalization phase is completed when the sum of daily vernalization rates has reached a value of one.

\section{Results}

Parameterization. Linear relationships were found between stem and leaf dry matter during the vegetative phase, i.e., at harvests one and two (Fig. 1A). There was no significant influence of $\mathrm{N}$ level on vegetative stem leaf distribution within light environments but shaded plants had higher stem/leaf ratios than nonshaded plants. However, the average specific leaf areas of shaded and nonshaded plants also differed significantly with $145.4 \pm 3.9$ and $93.0 \pm 8.1$ $\mathrm{cm} \cdot \mathrm{g}^{-1}$ respectively (LSD $=12.8 \mathrm{~cm} \cdot \mathrm{g}^{-1}$ ). Thus, a common linear relationship between stem mass and leaf area existed for all $\mathrm{N}$ and light treatments (Fig. 1B). The value of the parameter a (Eq. [3]) quantifying the increase in stem growth per increase in leaf area is determined by the slope of the regression line.

Differences in inflorescence dry weights among treatments at the second harvest of 1996 (Fig. 2) were partly significant (data 


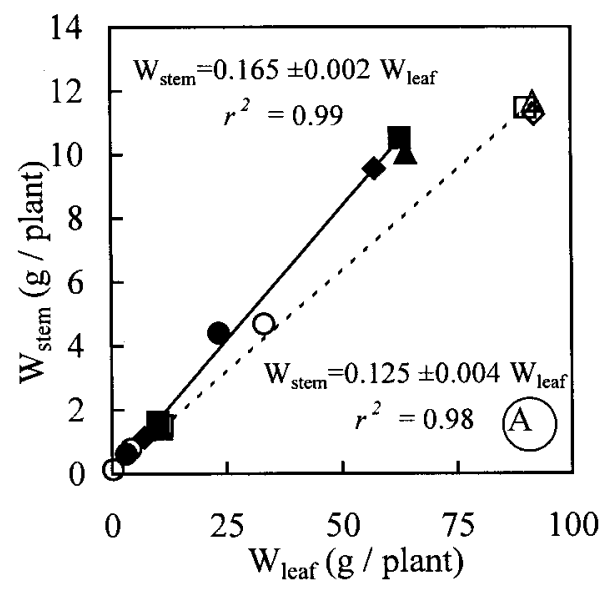

Fig. 1. (A) Measured stem $\left(\mathrm{W}_{\text {stem }}\right)$ vs. leaf dry weight $\left(\mathrm{W}_{\text {leaf }}\right)$, and (B) vs. leaf area, $\mathrm{A}_{1}$, for inflorescence dry weight $<1 \mathrm{~g}$, i.e., data from first two harvests where $\mathrm{W}_{\text {stem }}=\mathrm{W}_{\mathrm{s}, \mathrm{i}} ;[1996$ Expt.).Symbols: (L1-N0 (O); L2-N0 (O); L1-N1 (口); L2-N1 $(\square)$; L1-N2 $(\Delta)$; L2$\mathrm{N} 2(\boldsymbol{\Delta}) ; \mathrm{L} 1-\mathrm{N} 3$ (open diamond); L2-N3 (solid diamond)].

Fig. 2. Accumulation of inflorescence dry weight, $\mathrm{W}_{\text {in }} ; 1996$ Expt.; lines are simulations using Eqs. [7] and [11] with parameters given in Table 4. Symbols: (L1-N0 (O); L2-N0 (O); L1-N1 (口); L2-

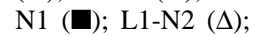
L2-N2 (A); L1-N3 (open diamond); L2N3 (solid diamond)].

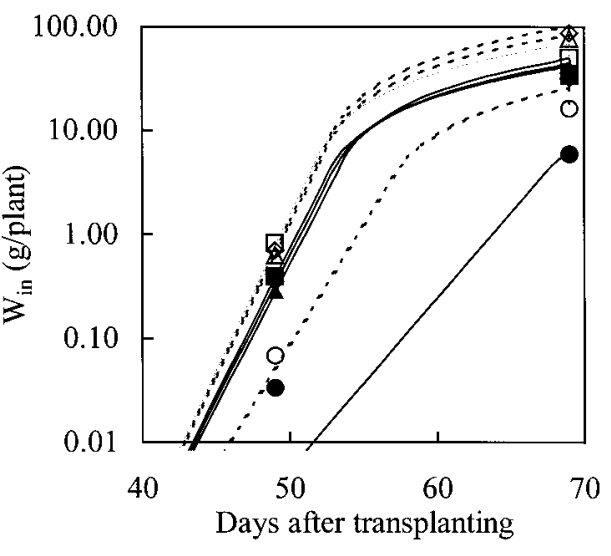

not presented) and were attributed to different specific inflorescence growth rates, $\operatorname{rgr}_{\text {in }}$ (Eq. 7). The parameter, $\operatorname{rgr}_{\text {in }}$, was estimated for each treatment separately by nonlinear regression analyses of measured and simulated $\mathrm{W}_{\mathrm{p}}$ (Table 4 ). The parameter, $\mathrm{rgr}_{\mathrm{in}}$, was related to the $\mathrm{N}$ status of the plant expressed as leaf $\mathrm{N}$ content per unit leaf area at the time when the vernalization phase was just completed, i.e., at harvest one (Fig. 3). The slopes of the $\mathrm{rgr}_{\text {in }}$-leaf $\mathrm{N}$ relationships obtained separately for the shaded and nonshaded treatments were not significantly different. The parameter, $\mathrm{f}_{\text {stem }}$, describing the increase in stem growth with increasing inflorescence weight (Eq. [9]), was estimated as $0.15 \pm 0.01$ and independent of treatment.
Agreement between simulated and measured fractions of individual organs on total dry matter for all harvests of the parameterization data set is presented in Table 5. Fractions of inflorescence on total dry weight were underestimated for both light environments at the final harvest which resulted in an overestimation in leaf dry matter.

Evaluation. Good agreement between calculated (Kage and Stützel, 1999) and measured leaf numbers for the 1997 evaluation experiment, suggested a sufficiently accurate simulation of time of inflorescence 0.5 $\mathrm{A}_{1}\left(\mathrm{~m}^{2} /\right.$ plant $)$

1.0 initiation (Fig. 4). Since average daily temperatures differed only slightly, there were no significant differences between light environments. The visible leaf numbers (diameter $>1 \mathrm{~cm}$ ) of the N0 treatments at the first and second harvests lie significantly below the $\mathrm{N}$ treatment means by one and two leaves, respectively (data not presented).

Specific inflorescence growth rates, $\mathrm{rgr}_{\mathrm{in}}$, were calculated by the regression equation given in Fig. 3 using leaf $\mathrm{N}$ contents from the first harvest on day 26 after transplanting. This date was closest to the simulated day of inflorescence initiation, i.e., days 29 and 30 after transplanting for the nonshaded and shaded environment, respectively. Due to the lower N contents in 1997, the specific inflorescence growth rates were below those of 1996 (Table 4). Average specific leaf areas of the shaded and nonshaded light environments in 1997 were $168.9 \pm 5.8$ and $116.0 \pm 8.4 \mathrm{~cm} \cdot \mathrm{g}^{-1}$, respectively, and served as input parameters to calculate leaf area from simulated leaf dry weights.

The overall model performance is presented in Fig. 5. After completion of vernalization, inflorescence growth has priority over vegetative growth which results in a steadily decreasing fraction of leaf in the above-ground dry matter at the end of the growing period. The model was able to reproduce accelerated inflorescence growth with better $\mathrm{N}$ status at the completion of vernalization. The agreement between simulated and measured fractions of individual organs on total dry matter is equally high for shaded and nonshaded light environments (Fig. 6). Unfortunately, no data on leaf dry weights and thus, no data on dry matter partitioning, were obtained for the final harvest of the L1-N2 and L1-N3 treatments. Model predictions are comparably accurate for the different organs (Table 5). The stem fractions show the least variation, resulting in a lower $r^{2}$. The model performance is of similar quality for the evaluation experiment as it is for the parameterization experiment.

Table 4. Specific inflorescence growth rates, $\operatorname{rgr}_{\text {in }}\left(\mathrm{d}^{-1}\right)$, for the parameterization and evaluation experiments; the latter were calculated by the regression equation in Fig. 3 using the leaf $\mathrm{N}$ contents, $\mathrm{n}_{\text {area }}$, of the first harvest in 1997.

\begin{tabular}{lccc}
\hline \hline & $\begin{array}{c}\text { Estimated } \\
\text { rgr }_{\text {in }} \pm \text { SE, } \\
\text { parameterization }\end{array}$ & $\begin{array}{c}\text { Calculated } \\
\text { rgr }_{\text {in }}, \\
\text { evaluation }\end{array}$ \\
Treatment & $0.70 \pm 0.05$ & 0.58 & 0.72 \\
L1-N1 & $0.99 \pm 0.05$ & 0.81 & 4.0 \\
L1-N2 & $0.97 \pm 0.05$ & 0.81 & 4.5 \\
L1-N3 & $0.98 \pm 0.05$ & 0.43 & 4.5 \\
L2-N0 & $0.46 \pm 0.03$ & 0.52 & 2.4 \\
L2-N1 & $0.91 \pm 0.05$ & 0.54 & 3.9 \\
L2-N2 & $0.87 \pm 0.05$ & 0.58 & 3.0 \\
L2-N3 & $0.89 \pm 0.05$ & 3.2 \\
\hline
\end{tabular}




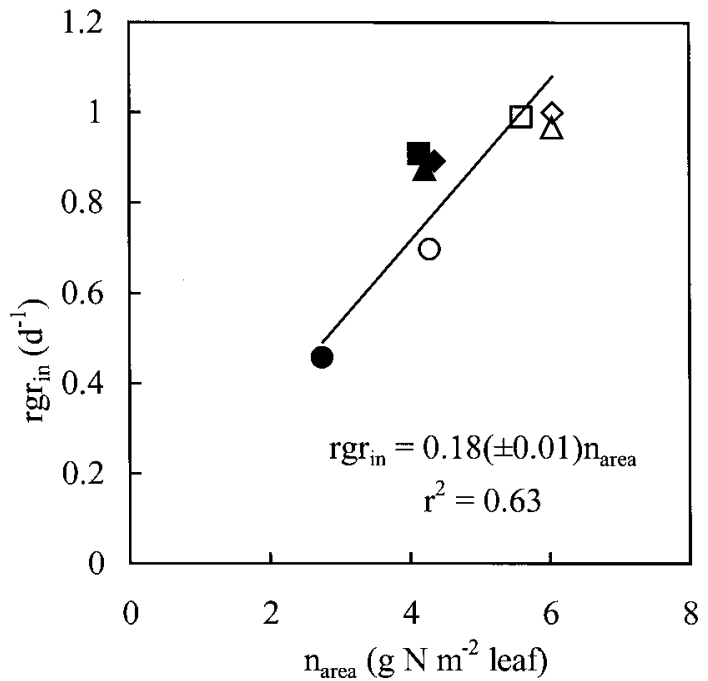

Fig. 3. Estimated specific growth rates of inflorescence, $\operatorname{rgr}_{\text {in }}$ (Table 4), as dependent on leaf $\mathrm{N}$ content per unit leaf area, $\mathrm{n}_{\text {area }}$; 1996 Expt. Symbols: (L1-

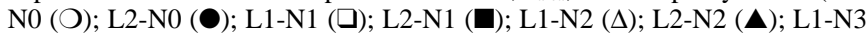
(open diamond); L2-N3 (solid diamond)].

Table 5. Results of the linear regression analyses ${ }^{\mathrm{Z}}$ of measured vs. simulated dry matter fractions of cauliflower organs in both experiments.

\begin{tabular}{llcc}
\hline \hline Experiment & Organ & Slope $\pm \mathrm{SE}$ & $r^{2}$ \\
\hline Parameterization & Stem & $1.04 \pm 0.03$ & 0.28 \\
Parameterization & Leaf & $1.01 \pm 0.01$ & 0.92 \\
Parameterization & Inflorescence & $0.80 \pm 0.02$ & 0.98 \\
Evaluation & Stem & $0.93 \pm 0.03$ & 0.22 \\
Evaluation & Leaf & $1.05 \pm 0.01$ & 0.82 \\
Evaluation & Inflorescence & $0.80 \pm 0.04$ & 0.92
\end{tabular}

${ }^{\mathrm{z}}$ Intercepts in all cases were not significantly different from zero.

\section{Discussion}

This study explored the extent to which dry matter partitioning in cauliflower is dependent on $\mathrm{N}$ status and light environment. The formulated hypotheses were evaluated in field experiments comprising four $\mathrm{N}$ fertilizer levels and two light regimes.

Allometric partitioning between stem and leaf has been proven under conditions of a relatively constant light environment (Kage and Stuitzel, 1999). The approach used in the present study was

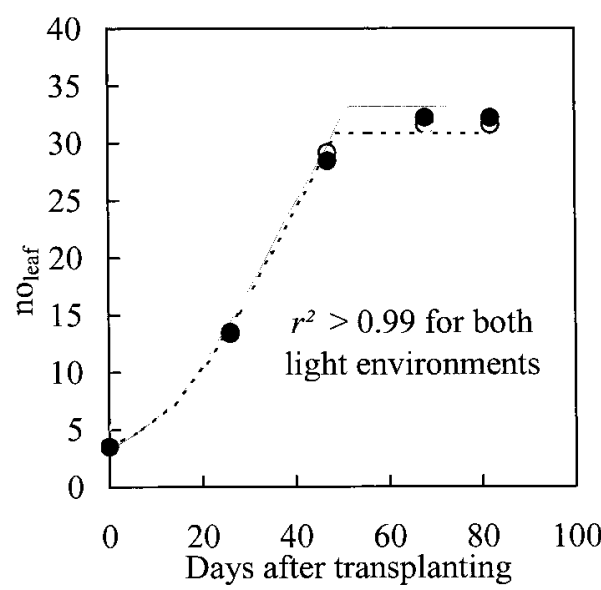
able to describe stem leaf distribution under variable irradiances. The quantitative relationship between stem dry weight and leaf area in this

Fig. 4. Calculated (lines) and measured (symbols) number of visible leaves per plant $($ no leaf $)$ means of shaded (closed symbols, solid line) and nonshaded $\mathrm{N}$ treatments (open symbols, dashed line) (1997 Expt.). model was independent of $\mathrm{N}$ supply. In a more comprehensive model, the planting density may also be a factor, since a single plant in a closed crop is protected by surrounding plants, but this was not examined herein.

Inflorescence growth was modelled using the concept of sink capacity as defined by the potential growth rate of the inflorescence under nonlimiting assimilate supply. Similar approaches, incorporating competition between different storage organs, have been used successfully in tomato (Lycopersicon esculentum Mill.) (Jones et al., 1991) and cucumber (Cucumis sativus L.) (Chamont, 1993). The relationship between sink capacity and leaf $\mathrm{N}$ status explained differences in inflorescence growth with $\mathrm{N}$ supply in cauliflower. The intrinsic relative growth rate, $\mathrm{rgr}_{\mathrm{in}}$, was dependent on the $\mathrm{N}$ status at the time of inflorescence initiation and is considered fixed from then on because the number of initiated cells is determined shortly after inflorescence initiation. A sensitivity analysis of $\operatorname{~rgr}_{\text {in }}$ on the fraction of inflorescence on total above-ground dry weight at the final harvest was performed for the 1997 Expt. Within the range of $\pm 10 \%$ around the calculated values, an increase in rgr $_{\text {in }}$ by $1 \%$ led to an increase in the fractions of inflorescence on total above-ground dry weight between $1.0 \%$ to $1.7 \%$, average $1.2 \%$, for the different treatments. Although $\mathrm{rgr}_{\text {in }}$ is the relevant parameter of the exponential growth phase of the inflorescence, sensitivity analysis revealed that the approach is of acceptable robustness. The observed dependence of the generative sink capacity on $\mathrm{N}$ supply during the initiation phase was also found for onions (Allium cepa L.) (Stuart and Griffin, 1945) and Kalanchoe (Kalanchoe blossfeldiana Poelln.) (Rünger, 1960).

Estimation of the parameter, $\mathrm{f}_{\text {stem }}$, describing the increase in stem growth with increasing inflorescence weight (Eq. [9]) to be $0.15 \pm 0.01$ implies a maximum fraction of inflorescence growth rate on total growth rate of 0.85 . This value is similar to 0.82 reported by Kage and Stützel (1999).

Comparison of visible leaf numbers (diameter $>1 \mathrm{~cm}$ ) showed no significant differences between the $\mathrm{N}$ treatments except for the N0 treatments at the first two harvests in 1997. Atherton et al. (1986), however, found that for 'Perfection' cauliflower the rate of leaf initiation was not affected by $\mathrm{N}$ deficiency. Since final leaf numbers of all treatments did not differ significantly, it was assumed for the simulations that the numbers of leaves initiated were the same for all treatments within one light environment at all times. The number of leaves initiated is decisive in determining the end of the juvenile phase. The lesser numbers of visible leaves in the N0 treatments at the first two harvests are attributed to a decreased
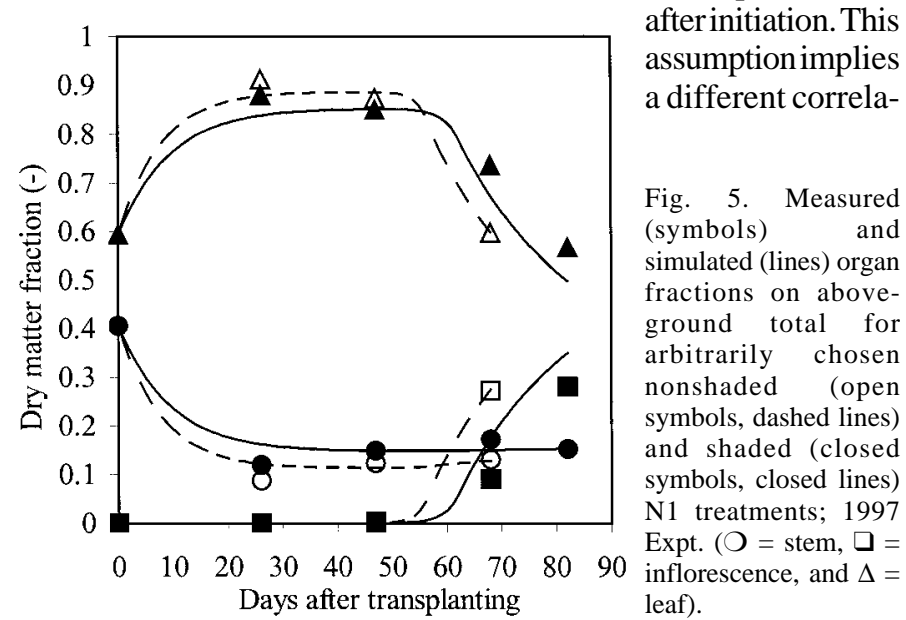

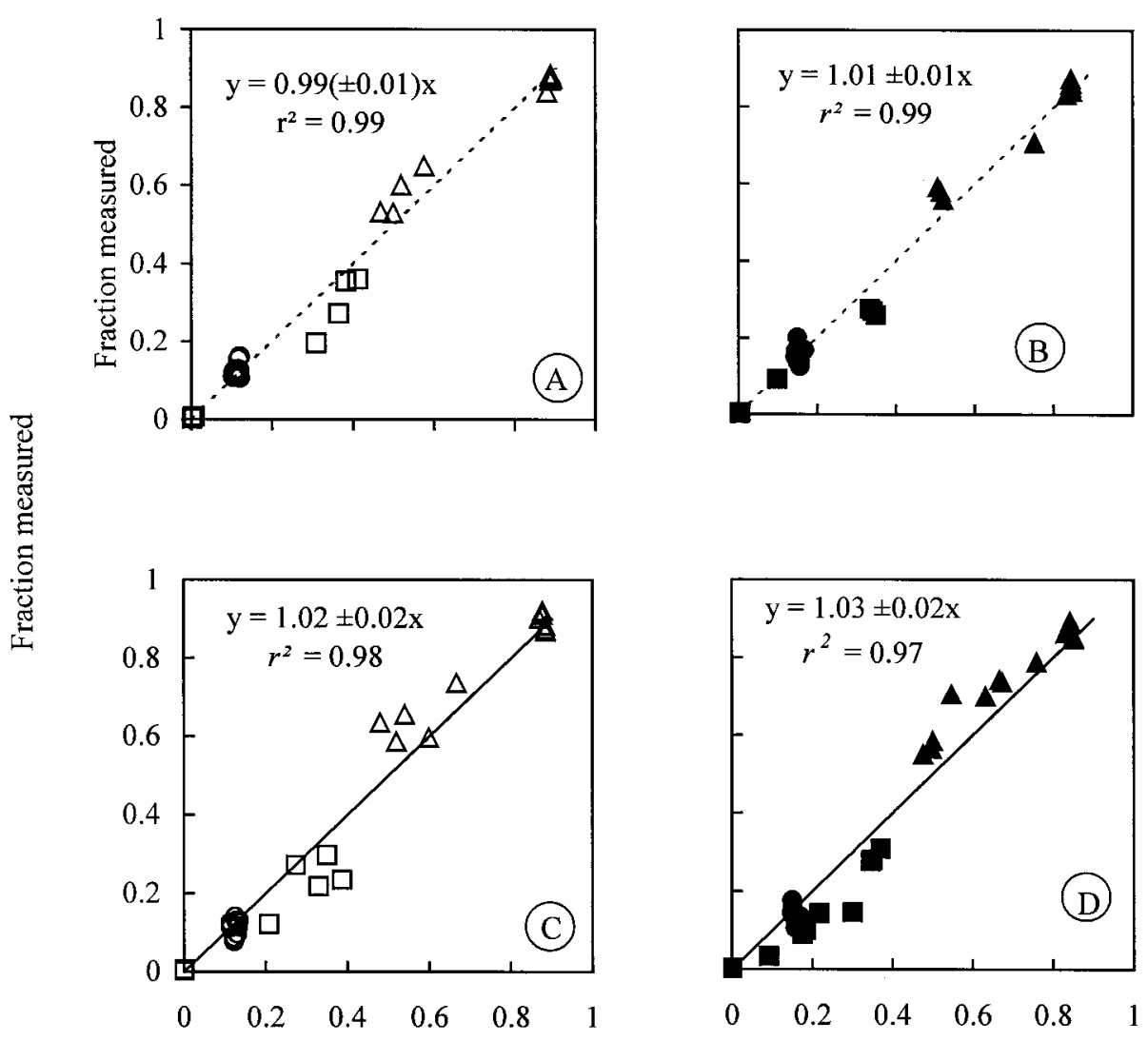

Fraction simulated

Fig. 6. Measured vs. simulated dry matter fractions (organ mass/above-ground total) of nonshaded ( $\mathbf{A}$ and $\mathbf{C}$ ) and shaded ( $\mathbf{B}$ and $\mathbf{D})$ treatments and all harvests; 1996 Expt. (A and B) and 1997 Expt. (C and D), $(O=$ stem, $\square=$ inflorescence, and $\Delta=$ leaf).

tion between initiated and visible leaf numbers in $\mathrm{N}$ deficient plants than that found by Booij and Struik (1990) for well fertilized plants.

In conclusion, a concept of above-ground dry matter partitioning as dependent on $\mathrm{N}$ supply and light environment was evaluated successfully in cauliflower using data from field experiments for parameterization and evaluation. The model was based on a functional dependency between stem and leaf area as well as a correlation of generative sink capacity on the $\mathrm{N}$ status of the plant. However, results of this study suggest that further research is needed on the interrelation of developmental and growth processes.

\section{Literature Cited}

Agren, G.I. and T. Ingestad. 1987. Root-shoot ratio as a balance between nitrogen productivity and photosynthesis. Plant Cell Environ. 10:579586.

Alt, C. 1999. Modelling nitrogen demand of cauliflower (Brassica oleracea L. botrytis) by using productivity-nitrogen relationships. PhD diss. Univ. of Hannover, Hannover, Germany. http:// edok01.tib.uni-hannover.de/edoks/e002/269915257.pdf.

Alt, C., H. Stützel, H., and H. Kage, 2000. Optimal nitrogen content and photosynthesis in cauliflower (Brassica oleracea L. botrytis). Scaling leaf to plant. Ann. Bot. 85:779-787.

Atherton, J.G., D.J. Hand, and C.A. Williams. 1987. Curd initiation in the cauliflower (Brassica oleracea conv. botrytis var. botrytis L.), p. 133-145. In: J. G. Atherton (ed.). Manipulation of flowering. Butterworths, London.
Biemond, H. 1995. Nitrogen nutrition effects on development, growth and nitrogen accumulation of vegetables. PhD diss. Wageningen Agr. Univ., Wageningen, The Netherlands.

Booij, R. and P.C. Struik. 1990. Effects of temperature on leaf and curd initiation in relation to juvenility of cauliflower. Scientia Hort. 44:201214.

Brouwer, R. 1962a. Distribution of dry matter in the plant. Neth. J. Agr. Sci. 10:361-367.

Brouwer, R. 1962b. Nutritive influences on the distribution of dry matter in the plant. Neth. J. Agr. Sci.10:399-408.

Chamont, S. 1993. Modelling dry matter allocation in cucumber crops. Competition between fruits and roots. Acta Hort. 328:195-204.

Farrar, J.F. 1993. Sink strength: What is it and how do we measure it? Plant Cell Environ. 16:1013-1046.

Gallant, A.R. 1987. Nonlinear statistical models. Wiley, New York.

Goudriaan, J. and J. L. Monteith. 1990. A mathematical function for crop growth based on light interception and leaf area expansion. Ann. Bot. 66:695-701.

Hirose, T. 1986. Nitrogen uptake and plant growth. II. An empirical model of vegetative growth and partitioning. Ann. Bot. 58:487-496. Johnson, I.R. and J.H.M. Thornley. 1987. A model of shoot:root partitioning with optimal growth. Ann. Bot. 60:133-142.

Jones, J.W., E. Dayan, L.H. Allen, H. Van Keulen, and H. Challa. 1991. A dynamic tomato growth and yield model (TOMGRO). Trans. Amer. Soc.

Agr. Eng. 34:663-672.

Kage, H., C. Alt, and H. Stützel. 2001a. Predicting dry matter production of cauliflower (Brassica oleracea L. botrytis) under unstressed conditions. I. Photosynthetic parameters of cauliflower leaves and their implications for calculations of dry matter production. Scientia Hort. 87:155-170.

Kage, H., C. Alt, and H. Stützel. 2001b. Predicting dry matter production of cauliflower (Brassica oleracea L. botrytis) under unstressed conditions II. Comparison of light use efficiency and photosynthesisrespiration based model modules. Scientia Hort. 87:171-190.

Kage, H., M. Kochler, and H. Stützel. 2000. Root growth of cauliflower (Brassica oleracea L. botrytis) under unstressed conditions: Measurement and modelling. Plant Soil 223:133-147.

Kage, H. and H. Stützel. 1999. A simple empirical model for predicting development and dry matter partitioning in cauliflower (Brassica oleracea L. botrytis). Scientia Hort. 80:19-38.

Levin, S.A., H.A. Mooney, and C. Field. 1989. The dependence of plant root:shoot ratios on internal nitrogen concentration. Ann. Bot. 64:71-75.

Marcelis, L.F.M. 1993. Simulation of biomass allocation in greenhouse crops-A review. Acta Hort. 328:49-67.

Marcelis, L.F.M. 1994. Fruit growth and dry matter partitioning in cucumber. PhD Diss., Inst. Agrobiol. Soil Fertility, AB-DLO-Res. Inst., Wageningen, The Netherlands.

Marcelis, L.F.M., E. Heuvelink, and A.N.M. De Koning. 1989. Dynamic simulation of dry matter distribution in greenhouse crops. Acta Hort. 248:269-276.

Marquardt, D.W. 1963. An algorithm for least-squares estimation of nonlinear parameters. J. Soc. Ind. Appl. Math. 11:431-441.

Munns, R. and G.R. Cramer. 1996. Is coordination of leaf and root growth mediated by abscisic acid? Opinion. Plant Soil 185:33-49.

Olesen, J.E. and K. Grevsen. 1997. Effects of temperature and irradiance on vegetative growth of cauliflower (Brassica oleracea L. botrytis) and broccoli (Brassica oleracea L. italica). J. Expt. Bot. 48:1591-1598.

Pearsall, W.H. 1927. Growth studies. VI. On the relative sizes of growing 
plant organs. Ann. Bot. 41:549-556.

Penning de Vries, F.W.T., D. M. Jansen, H.F.M. ten Berge, and A. Bakema. 1989. Simulation of ecophysiological processes of growth in several annual crops. Pudoc. Wageningen, The Netherlands.

Reynolds, J.F. and J. Chen. 1996. Modelling whole-plant allocation in relation to carbon and nitrogen supply: Coordination versus optimization. Plant and Soil 185:65-74.

Rünger, W. 1960. Über den Einfluß der Stickstoffernährung und der Temperatur während Langtag- und Kurztagperiode auf die Blütenbildung von Kalanchoe blossfldiana. Planta 56:517-529.

SAS Inst., Inc. 1988. SAT/STAT user's guide, release 6.03 ed. SAS Inst., Cary, N.C.

Stuart, N.W. and D.M. Griffin. 1945. The influence of nitrogen nutrition on onion seed production in the greenhouse. Proc. Amer. Soc. Hort. Sci. 48:398-402.

Stützel, H. and W. Aufhammer. 1991. Canopy development of a determinate and an indeterminate cultivar of Vicia faba L. under contrasting plant distributions and densities. Ann. Appl. Biol. 118:185-199.

Thornley, J.H.M. and I.R. Johnson. 1990. Plant and crop modelling: A mathematical approach to plant and crop physiology. Clarendon Press, Oxford, U.K.

Van der Werf, A. and O.W. Nagel. 1996. Carbon allocation to shoots and roots in relation to nitrogen supply is mediated by cytokinins and sucrose. Opinion. Plant Soil 185:21-32.
Walker, A. 1997. ModelMaker. Cherwell Scientific, Oxford, U.K.

Warren-Wilson, J. 1967. Ecological data on dry-matter production by plants and plant communities, p. 77-123. In: E.F. Bradley and O.T. Denmead (eds.). The collection and processing of field data. CSIRO, Sydney, Australia.

Wheeler, T.R, R.H. Ellis, P. Hadley, and J.I.L. Morison. 1995. Effects of $\mathrm{CO}_{2}$, temperature and their interaction on the growth, development and yield of cauliflower (Brassica oleracea L. botrytis). Scientia Hort. 60:181-197.

Wiebe, H-J. 1972a. Wirkung von Temperatur und Licht auf Wachstum und Entwicklung von Blumenkohl. II. Optimale Vernalisationstemperatur und Vernalisationsdauer. Gartenbauwissenschaft 37:293-303.

Wiebe, H-J. 1972b. Wirkung von Temperatur und Licht auf Wachstum und Entwicklung von Blumenkohl. III. Vegetative Phase. Gartenbauwissenschaft 37:455-469.

Wien, H.C. 1997. Correlative growth in vegetables, p. 181-206. In: H.C. Wien (ed.). The physiology of vegetable crops. CAB Intl., Wallingford, U.K.

Wolfswinkel, P. 1985. Phloem unloading and turgor-sensitive transport: Factors involved in sink control of assimilate partitioning. Physiol. Plant. 65:331-339.

Wurr, D.C.E, J.R. Fellows, R.A. Sutherland, and E.D. Elphinstone. 1990. A model of cauliflower curd growth to predict when curds reach a specified size. J. Hort. Sci. 65:555-564. 